\title{
DEVELOPING ENGLISH TEXTBOOK IN ELEMENTARY SCHOOL BASED ON LOCAL WISDOM OF BANYUWANGI
}

\author{
Nur Hasibin ${ }^{1}$, Arin Inayah ${ }^{2}$ \\ ${ }^{1}$ English Educational Departement, Language and Art Faculty, PGRI University of \\ Banyuwangi \\ hasibinnur@gmail.com \\ ${ }^{2}$ English Educational Departement, Language and Art Faculty, PGRI University of \\ Banyuwangi \\ arin.inayah90@gmail.com
}

\begin{abstract}
This study aims to develop an English textbook based on Banyuwangi local wisdom. The design used is research and development $(R \& D)$ using Borg and Gall models, namely; 1) Preliminary study (define) and design (design); 2) Textbook development (Development); (3) the model testing phase, and 4) Dissemination of implementation (development, validation, and testing) of textbook development results. The data collecting methodis a qualitative data from the result of interviews, questionnaires, and document analysis. There were 12 teachers as respondents and three experts in providing input on the research prototype. The results of this study indicate that the process of developing textbooks includes an introduction in the form of a map of the teacher's need for textbooks based on local wisdom of Banyuwangi. The design stage includes a book draft, and the development stage is the final of textbook result. Assessment is using to know the quality of textbooks from the material, presentation, language, and graphics components. The material components get good ratings, good presentation, good language, and good graphics.
\end{abstract}

Keywords: Developing; textbooks; local wisdom

Banyuwangi has implemented English in elementary schools to the same degree as a local content lesson from 2001 until now. This suit with Permendikbud number 79, 2014 concerning the 2013 curriculum, which states that local content can be in the form of arts, crafts, physical education, sports, and health.

The regulation is not stated specifically, so that schools must adjust to choose local content based on social, cultural, conservation, and development of useful local wisdom and can enhance national development.

Teaching English in elementary schools in Banyuwangi, the level of success in language learning will depend heavily on textbooks, teaching planning (syllabus, material), and implementation in the field such as the ability of teachers to interact in class, facilities, classroom settings, and others.

English textbooks are really needed in 
teaching and learning process to get maximum results. Textbooks are also used as evaluation material, as a tool for educators in implementing the curriculum, and as a determinant of teaching methods or techniques that educators will use.

Based on the classification carried out by the Bookkeeping Center of the Ministry of National Education on educational books (2004: 4), it is revealed that there are four types, namely textbooks, enrichment books, reference books, and educator manuals. This classification is further strengthened by the Regulation of the Minister of National Education Number 2 of 2008 article 6 paragraph (2) which states that "Apart from textbooks, educators can use books, teacher guides, enrichment books, and reference books in the learning process". Based on these provisions, there are four types of books used in the field of education, namely (1) Textbooks, (2) Enrichment Books, (3) Reference Books, and (4) Educator Manuals.

To make easy in classification and give meaning of educational books, it is classified by two groups which are determined based on the scope of authority in quality control, namely (1) Textbooks and non-textbooks. Non-textbook lessons, according to Permendikbud No. 8 of 2016 concerning books used by education units, it is stated that the authority to assess the eligibility criteria for textbooks and non-textbooks is the Ministry or the National Education Standards Agency (BSNP), while enrichment books, references, and educator guides are not under their authority.

Based on the explanation above, non-text textbooks are different from textbooks. When examined based on lexical meaning, textbooks are books used to study or deepen an object of knowledge and science and technology or a field of study. Meanwhile, non-text textbooks are books that are not used directly as books to study a field of study in educational institutions.

Based on the explanation above, the characteristics of non-textbooks can be classified as follows. 1) Books that can be used in schools or educational institutions but are not the main handbooks for students to participate in learning activities. 2) Books that do not present learning materials that are equipped with evaluation instruments in the form of tests or tests, work exercises (LKS) or other forms that require readers to carry out the instructions expected by the author. 3) Non-text books are not published in series based on class or education level. 4) Nontext books contain material that is not directly tied to some or one of the Competency Standards or Core Competencies contained in the Content Standards, but they have a connection in supporting the achievement of national education goals. 5) The material or content of non-text textbooks can be used by readers from all levels of education and grade levels or across readers, so that non-textbook material can also be used by readers in general. 6) The presentation of non-text textbooks is loose, creative, and innovative so that it is not tied to the provisions of the learning process and systematics which are determined based on the science of education and teaching.

By referring to the characteristics of these non-text textbooks, it can be stated that nontext textbooks are books that contain supporting material, complementary, and supporting textbooks that function as enrichment, reference, or guidance in educational and learning activities. By using a presentation that is loose, creative, and innovative and can be used by readers across levels and levels of class or general readers.

Prastowo (2014), explains that textbooks are books that are compiled for the learning process and contain materials or subject matter to be taught. The book contains knowledge derived from the basic competencies contained in the curriculum. Textbooks are used by students to learn. Textbooks have a strategic position to improve the quality of Human Resources (HR) because it is an important part of learning in schools. According to Situmorang (2013), the development of standard textbooks through learning innovation by integrating character education 
needs to be done to fulfill good quality teaching materials that can improve Indonesia's human resources good character.

Textbooks also have function as manuals for students in learning and for teachers in teaching students, certain fields of study or subjects. Students use textbooks to prepare themselves before starting lessons in class so that they can have good interactions in the learning process and can work on assignments given by the teacher, and can prepare for tests or exams. According to Prastowo (2014), textbooks are a form of printed teaching material, whose structure consists of four components, namely titles, basic competencies or subject matter, exercises, and assessments.

Researchers argue that currently textbooks emphasize the ability of students' intellectual intelligence and less discussed emotional intelligence or social intelligence and there are no textbooks based on local wisdom of Banyuwangi Regency. Textbooks like this cause boring because the material taught is less attractive and feels foreign to students. Therefore, it is necessary to procure quality books that are fun and provide insight into the culture, tourism, regional-based customs, including sourcebooks/reference and books/enrichment books that can be used by teachers to carry out various developments and learning innovations.

From the description above, the researcher can find four main problems. The problems that can be identified from the above background are (1) the scarcity of textbooks both in terms of quality and quantity; (2) textbooks currently only emphasize academic ability, are not accompanied by things that can improve and (3) reference books are scarce for English subjects.

Based on the identification of the problems, the researcher determined the concentration of research on the first and second problems, namely those related to the scarcity of textbooks for English subjects that have qualities that can improve intellectual, social intelligence, and know local wisdom of Banyuwangi Regency. So, the researchers want to do research entitled "Developing English textbook in elementary school based Banyuwangi local wisdom. According to Education and Culture (2011), local wisdom is a local cultural wealth that contains a policy of life, a way of life that accommodates wisdom and life wisdom, which does not only apply locally to certain culture or ethnicity but across cultures or across ethnicities so as to form cultural values that are national in nature. Local wisdom contains ethics and moral values contained in local wisdom taught from generation to generation, passed down from generation to generation.

What has been taught from generation to generation, comes from life experiences, indigenous knowledge, and local wisdom. In the past, it is still often used in everyday life. Utami and Haneda (2010) argue that over time, local wisdom has begun to be forgotten since the entry of modern things, and people prefer synthetic things because they are considered more practical, cheaper, easy, and the results can be seen immediately. Since ancestral wealth is increasingly being abandoned and forgotten, today's younger generations tend to no longer care and do not know about the ancestral heritage contained in a traditional culture that has local wisdom. Rahyuni et al. (2013) argues that the abandoned traditional culture will automatically eliminate the value of local wisdom which has an impact on environmental damage, and a decrease in the knowledge of the younger generation about local wisdom.

Kompas (2019), the people who live in Banyuwangi are the Osing people. Indiarti (2013) explains that the Osing community has rules in maintaining environmental balance. The practices carried out by the Osing community are usually in agriculture. In rice cultivation activities, there are 9 processions that must be carried out by the Osing community. The processions are, dhawuhan, labuh nyingkal, nyawani ngurit, labuh tandur, ngrujaki, nylameti sawah, metik, moringa nggampung and ngunjal. Each of these processions contains the 
community's hope that God will give maximum results. This shows that religious values are highly respected by the Osing community in Banyuwangi.

The OSING community in Banyuwangi also has a variety of cultures that are manifested from agriculture in the form of arts. The types of traditional arts that are still exist today are Gandrung, Kebo-Keboan, Barong Ider Bumi, and Mocoan Lontar Yusuf. Government of Banyuwangi Regency is very supportive of the preserve local culture by including it in the annual event calendar of the Banyuwangi Regency.

The OSING community in Banyuwangi has local wisdom in the manifestation of traditional house architecture. The traditional house of the OSING tribe has three factors that guide the construction of a house. The three factors according to Suprijanto (2002) are environmental factors, house shapes, and patterns are based on patterns of adaptation to climatic and geographic conditions in Banyuwangi Regency. A sparring system is a form of local wisdom where the OSING community can adapt through the traditional houses that have been made. Local wisdom that can be interpreted from environmental factors is always adapting to the environment and maintaining the balance of nature.

Social factors, the shape of the traditional OSING house can be recognized by the shape of the roof, namely cerogogan, baresan, and tikel balung. This form shows that the OSING community does not recognize hierarchies and social strata. Local wisdom that can be understood from this factor is that the OSING community has the same position in the eyes of God, so there is no need for a hierarchy in the social system because hierarchy will only separate the brotherhoods.

Based on religious or belief factor, the Osing house is a form of embodiment of the whole universe in a smaller form. The OSING settlement pattern has a north-south orientation and does not face mountains. Local wisdom which is based on the belief factor is that the OSING community always remembers God through the house they have made. Some of the local wisdom values of the OSING tribe in Banyuwangi are dominated by belief in God. The OSING community inherits from their ancestors in the form of an attitude that is always grateful to God. Thanking God is an obligation for humans who have been created into the world.

\section{METHOD}

This study aims to develop English textbooks for SD / MI levels based on Banyuwangi local wisdom. The developing model used in this study are the Borg and Gall models. This development model is simplified by Sukmadinata (2008) divides the steps into four main stages. The four stages are (1) the exploration or preliminary stage, (2) the model development stage, (3) the model testing phase, and (4) the model dissemination and implementation stage. Below is described the operational steps of the research at each stage.

The subjects of this study were English Subject Teachers at 12 elementary schools in Banyuwangi Regency. The primary schools are 1. SDN 1 Benelanlor 2. SDN 1 Bunder 3. SDN 1 Bareng 4. MI Darul Falah Gombolirang 5. MI Nurul Huda Macan putih 6. MI Sunan Ampel 7. SDN 2 Tukang kayu 8. SDN 1 Kertosari 9 SDN Model 10. MI Darun Najah 11. MIN Sobo 12. MI Islamiyah Dadapan. The plan for the implementation of this research is approximately 8 months. While the object of research is the document of English learning.

\section{FINDING}

Teacher's need for English Textbooks. The analysis of teacher needs for English textbooks based on Banyuwangi local wisdom consists of 8 aspects, namely: 1) teachers 'understanding of textbooks, 2) teacher opinions about textbooks, 3) learning resources in teaching English, 4) teachers' understanding of local wisdom, 5) the need for content about English textbooks based on 
local wisdom of Banyuwangi, 6) physical needs for English textbooks based on local wisdom. 7) Physical needs of textbooks. 8) teachers' expectations of local wisdom-based English textbooks.

\section{Teachers' Understanding of Teaching Materials}

There were 12 respondents to answer the question "Do you know what a textbook is". From 12 respondents, 11 answered yes and 1 answered no. and 7 respondents answered "yes", 4 respondents answered no, and 1 respondent did not answer the question "Are textbooks similar to textbooks/textbooks?". From this analysis, it can be seen that in general, the respondents understand textbooks.

\section{Teachers' Opinions to Textbooks}

12 respondents answered very importantly to the question "How do you view basic English textbooks?" and one respondent chose very importantly and important. So that it can be seen that the respondents really want English textbooks.

\section{Resources for learning in teaching English} From the question "What do you use in teaching English?" Some respondents choose more than one answer, including the one used by the respondent to teach is a textbook with two respondents and 10 respondents using LKS and three respondents using the internet

The second question was to determine the availability of textbooks, 4 respondents answered that there were textbooks in their schools and 4 respondents answered that there were no textbooks while the others did not answer.

The third question is to find out where textbooks can be obtained, some respondents respond to more than one answer. 5 respondents get from textbooks / BSE, 6 respondents get from student worksheets.

\section{Teachers' understanding of local wisdom} From a total of 12 respondents regarding the teacher's understanding of local wisdom, 10 teachers already understood and knew about local wisdom, while 2 teachers still did not understand what local wisdom was. In general, the respondents already understand and know local wisdom.

\section{The need for content about English textbooks based on local wisdom of Banyuwangi.}

All teachers (12 respondents) agreed that the English textbook was accompanied by competency standards, basic competencies, and indicators. Respondents also agreed on the availability of English textbooks that could serve as learning guides for students. Furthermore, there were 11 respondents (teachers) from a total of 12 respondents who stated the importance of developing textbooks based on local wisdom, while 1 respondent did not provide an answer. Furthermore, regarding the appropriate content for textbooks based on local wisdom developed for learning English, 8 respondents chose to use images based on local wisdom, 5 respondents used text-based on local wisdom, and 8 respondents chose to use other textbook contents. In the insertion of Banyuwangi local wisdom in English textbooks at the elementary school level, 10 respondents agreed that Banyuwangi local wisdom could be entered slowly in textbooks, while 2 respondents did not agree with it. Then, the next aspect regarding how to insert local wisdom in English textbooks, 10 respondents (teachers) chose to use examples in learning materials, while 2 respondents chose to use illustrations for inserting local wisdom in English textbooks. In the aspect of local cipher-based textbooks, 12 respondents wanted textbooks containing the essence of local wisdom, examples, and practice questions in the form of books, and 2 related respondents also simultaneously selected teaching materials that contained the essence of local wisdom and textbooks that contained the essence of local wisdom, examples and practice questions in book. Concerning the explanation of local wisdom in textbooks, all 
(12) respondents agreed that the textbook explained in more detail what local wisdom was. Regarding the textbook developed and containing sample questions, there were 12 teachers (respondents) who argued that the textbook must contain steps to do work that were coherent and easy to understand, another respondent argued that the textbook did not only contain steps to work coherently and easy to understand, but also must go directly to the answer to the question in question. Also, in terms of evaluation, 10 respondents agreed to use a multiple-choice survey, while 7 respondents chose the form of description. The last aspect about the language and spelling used in teaching materials, it can be concluded that 4 respondents stated that and the spelling must use proper diction, 6 respondents agreed to use spelling and punctuation according to the spelling that has been perfected, and 8 other respondents choose the use of effective sentences as the perfection of language and spelling in teaching materials.

\section{Physical needs about local wisdom-based English textbooks}

All respondents (12 teachers) agreed that the table of contents should be included in the textbook. Second, 10 respondents agreed if the instructions for using books were included in the textbook, while the other 2 respondents did not. Third, regarding the inclusion of glossaries in local wisdom-based textbooks, all responses (12 teachers) agreed. Fourth, 11 respondents agreed on the importance of including bibliography in local wisdom-based textbooks, while 1 respondent said they were not. The last one, which is related to the need to present a summary of the material in each chapter, 11 respondents agreed that it needed to be presented, while 1 respondent chose not to agree with the inclusion of the material summary.

\section{The needs to a cover of textbook}

Based on the results of the analysis, all respondents (12 people) agreed that an attractive textbook cover is illustrated and colorful. Second, regarding textbook illustrations, one respondent chose animation/cartoon as the appropriate illustration for the textbook cover, while eleven other respondents chose photos as the appropriate illustrations for textbooks, and no respondent chose caricatures as textbook illustrations. Third, with regard to the questions regarding the placement of illustrations, eleven respondents agreed if the illustrations were to be placed under the title with the appropriate size, while no respondents chose the placement of the illustrations on the sidelines / between titles and under the title of almost one page. Fourth, there were six respondents who agreed that the illustrations included in the textbook were only one illustration, while the other six respondents agreed if the illustrations in the textbook were more than two, and no respondent chose the two illustrations (number) that were included in the textbook. . Fifth, all (12) respondents stated that the size of the images included in the textbook must be medium, not small or large. Sixth, with regard to the front cover of textbooks, there were two respondents (teachers) who chose striking colors for the front cover of textbooks, while ten teachers chose soft colors for the front cover of textbooks, and none of them agreed to choose black and white color as the front cover of textbooks. Finally, in the questions regarding the suitability of the content to fill in the back cover of a textbook, one respondent agreed that the back cover of the textbook was filled with the contents of the book, while the other eleven respondents chose the author's biography to be included on the back cover of the textbook. Textbook Cover Needs

Based on the results of the analysis, all respondents (12 people) agreed that an attractive textbook cover is illustrated and colorful. Second, regarding textbook illustrations, one respondent chose animation/cartoon as the appropriate illustration for the textbook cover, while eleven other respondents chose photos as the appropriate illustrations for textbooks, and no respondent chose caricatures as textbook 
illustrations. Third, with regard to the questions regarding the placement of illustrations, eleven respondents agreed if the illustrations were to be placed under the title with the appropriate size, while no respondents chose the placement of the illustrations on the sidelines / between titles and under the title of almost one page. Fourth, there were six respondents who agreed that the illustrations included in the textbook were only one illustration, while the other six respondents agreed if the illustrations in the textbook were more than two, and no respondent chose the two illustrations (number) that were included in the textbook. . Fifth, all (12) respondents stated that the size of the images included in the textbook must be medium, not small or large. Sixth, with regard to the front cover of textbooks, there were two respondents (teachers) who chose striking colors for the front cover of textbooks, while ten teachers chose soft colors for the front cover of textbooks, and none of them agreed to choose black and white color as the front cover of textbooks. Finally, in the questions regarding the suitability of the content to fill in the back cover of a textbook, one respondent agreed that the back cover of the textbook was filled with the contents of the book, while the other eleven respondents chose the author's biography to be included on the back cover of the textbook.

\section{The Needs for Size and Font in Textbook Title}

As with the data from the analysis, ten teachers chose the font type (writing style) times new romance to be used in writing textbook titles, while one respondent chose Arial writing style, and no respondent chose comic sans ms writing style for writing book titles. teach. Then, in the second question item about the letter size in textbooks, ten out of a total of twelve teachers agreed to use the large size, while the other two teachers chose the medium size, and none agreed to choose the small size in textbook writing.

\section{Aspects of size needs and thickness of textbook}

Based on the citation of the analysis results, first, the booklet was chosen by one respondent as the textbook size, while the ledger was chosen by eleven out of a total of twelve respondents to be used as the textbook size, and none of the respondents chose the pocketbook size. Second, nine respondents stated that the appropriate book thickness for teaching materials was 30-40 pages, but three other respondents stated that 40-50 pages were the appropriate book thickness for teaching materials, and no respondent chose 50-60 pages. as the standard thickness of the teaching material book.

\section{The hope of the teachers for elementary level English textbooks}

based on Banyuwangi local wisdom, members: Can facilitate the teaching and learning process, can be used as a teaching material that increases students' knowledge of various local wisdom. the availability of textbooks that suit the needs of students, are effective, and efficient when used in learning, Textbooks that help achieve KI and $\mathrm{KD}$, Textbooks that can provide varied materials in learning, Aangagang books create fun learning, atmosphere textbooks based on local wisdom can be applied in everyday life, so that students can understand and understand about the culture in Banyuwangi, Can give books to be developed, Students get to know local wisdom in Banyuwangi and add insight into local wisdom, Textbooks that will be compiled contain grammar which is easily understood by elementary school level students, based on the results of data interviews,

obtained as follows: Most students are enthusiastic about participating in learning English, Most teachers teach using lks, English learning has been running smoothly, Most of the results are above KKM, Difficulty is easy to apply but still needs help to improve student quality, Teacher 
difficulties are teaching speaking lessons using different letters and pronunciations, contextual reading types with local wisdom, Strongly agree and hope will soon be realized

Based on document analysis carried out on English teaching materials at SD: Most of English teachers use student worksheets (LKS) as teaching materials. The contents of the other members' LKS are: Annual program, a semester program, lesson plan (RPP), syllabus, and material that is equipped with questions, The form of content in the LKS itself is a summary of the material and practice questions. A summary of the material presented is in the form of listening, speaking, reading, and writing. The material of the fourth skill is adjusted to the theme and is also equipped with practice questions, each final theme is presented or called a competency test and is also equipped with practical and remedial activities.

\section{Prototype test results from experts Aspects of material delivery}

In teaching and learning activities, the aspect of delivering material is one of the stages of the learning process that is important for both students and teachers because it is closely related to the level of success for teachers in delivering material and the success of students in understanding the subject matter. The following are details of the results of the analysis that we have carried out on aspects of the delivery of the material;

Based on the results of the analysis above, in the first question item, there were two out of three total respondents who stated that the suitability of the material presentation technique in teaching materials with the students' understanding was conveyed well, while one respondent said it was sufficient. Then, in the second question item, out of a total of three respondents, two respondents considered it good, and one respondent considered it sufficient about the suitability of the order of presentation of the material in the elementary level English textbook based on Banyuwangi local wisdom in Kab. Banyuwangi.

\section{Aspects of Material Content}

Aspects of the content of the material in the process of teaching and learning activities can be detailed as follows;

Referring to the results of the analysis, there is a general conclusion regarding 11 questions about aspects of the content of the material, in which all respondents (3 people) gave (equal) good ratings to; the suitability of the title with the language topic in the textbook, the completeness of the material presented in the textbook, the suitability of the local wisdom topic in the textbook with the level of understanding of the basic level students, the effectiveness of the examples presented in the textbook, the effectiveness of the exercises presented in the textbook, the effectiveness the questions/competency tests presented in the textbook, the suitability of questions to the level of understanding of elementary school students, the effectiveness of examples to instill an understanding of local wisdom to students, and the effectiveness of exercises to instill an understanding of local wisdom in students.

\section{Aspects of language and readability}

Concerning the aspects of language and readability, five questions were used as a reference for the research by the research team. The details of the results of the analysis are that all respondents gave a good assessment of the language selection in the title of basic level English textbooks based on Banyuwangi local wisdom in Kab. Banyuwangi, the choice of words used in English textbooks based on local wisdom, and the appropriateness of the use of spelling used in textbooks. Then, in the question items about "How is the suitability of language use with basic level students' cognitive development?", Two respondents rated it as good and one respondent considered it sufficient. Furthermore, in the question item about the suitability of the explanation in textbooks with the readability level of elementary level students, two 
respondents stated that the suitability of the explanation in the textbook with the readability level of elementary students was sufficient, while one respondent said it was good.

\section{Graphic aspects}

For the sake of smooth and easy teaching and learning process, of course, the graphic/visual aspects have an important role in learning activities. Therefore, the research team has conducted research on the aspects of graphics with the following results;

After further review and analysis of the graphic aspect, one out of three respondents gave a sufficient assessment of the attractiveness of the basic level English textbook title based on Banyuwangi local wisdom in Banyuwangi Regency, the creativity of English textbook titles at SD level based on Banyuwangi local wisdom in Regency. Banyuwangi, and the suitability of the size, color, and layout of the illustrations on the cover of the textbook, while the other two respondents gave good ratings. Furthermore, all respondents agreed to give a good assessment, there were six last questions about; suitability of the illustration with the topic of elementary school English textbooks based on local wisdom of Banyuwangi in Kab. Banyuwangi, the color composition of English textbooks at SD level based on Banyuwangi local wisdom in Kab. Banyuwangi, the selection of fonts in English textbooks at SD level based on Banyuwangi local wisdom in Kab. Banyuwangi, the size of the letter (font) in English textbooks at SD level based on Banyuwangi local wisdom in Kab. Banyuwangi, the size of an English textbook for SD level based on Banyuwangi local wisdom in Kab. Banyuwangi, and thick English textbooks at SD level based on Banyuwangi local wisdom in Kab. Banyuwangi.

\section{Conclusion}

From the formulation of the problem and discussion on the aspects of the teacher's need for English textbooks at the elementary school level, it can be concluded that 12 respondents wanted an English textbook based on Banyuwangi local wisdom. And from the results of the prototype test, it can be concluded that the experts gave good scores from each aspect, namely aspects of material delivery, aspects of material content, aspects of language and readability, aspects of graphics.

\section{REFERENCES}

Prastowo, A. 2014. Panduan Kreatif Membuat Bahan Ajar Inovatif. Yogyakarta: DIVA Press.

Sitepu, B. P. 2012. Penulisan Buku Teks Pelajaran. Bandung: PT Remaja Rosdakarya Offset. Situmorang, M. 2013. Pengembangan Buku Ajar Kimia SMA melalui Inovasi Pembelajaran dan Integrasi Pendidikan Karakter untuk Meningkatkan Hasil Belajar Siswa. Prosiding Semirata FMIPA Universitas Lampung.

Utami, S., dan Haneda, N. F. 2010. Pemanfaaatan Etnobotani dari Hutan Tropis Bengkulu sebagai Pestisida Nabati. JMHT, XVI (3): 143-147.

Rahyuni, Yuniati, E., dan Pitopang R. 2013. Kajian Etnobotani Tumbuhan Ritual Suku Tajio di Desa Kasimbar Kabupaten Parigi Moutong. Jurnal of Natural Science, 2 (2): 46-54.

Indiarti, W. 2013. Pengembangan Program Desa Wisata dan Ekowisata Berbasis Partisipasi Masyarakat di Desa Kemiren Kabupaten Banyuwangi. Banyuwangi: Badan Perencanaan Pembangunan Daerah Kabupaten Banyuwangi
Kompas.
2019.
Berkenalan
Dengan
Suku
Osing.

https://pesonaindonesia.kompas.com/read/2019/09/21/220537127/berkenalan-dengan- 
suku-

Osing\#: :text=KOMPAS.com\%20\%2D\%20Laros\%20Osing\%20(,sejak\%20ratusan $\% 20$ tahun\%20yang\%20lalu.

$\ll \mid 38$ 